\title{
Seasonal distribution of phenolics in leaves of aromatic plants (Origanum vulgare L., Mentha spicata L., Clinopodium vulgare L.) and their ecophysiological implications
}

\author{
GEORGE KOFIDIS and ARTEMIOS M. BOSABALIDIS
}
Department of Botany, School of Biology, Aristotle University, Thessaloniki 54124, Greece
Corresponding author: Artemios M. Bosabalidis, artbos@bio.auth.gr

(Received on 23 February 2011; Accepted on 4 March 2012)

\begin{abstract}
Seasonal distribution of phenolics was studied in leaves of 3 species of the family Lamiaceae: Origanum vulgare L., Mentha spicata L., and Clinopodium vulgare L. Phenolic compounds were identified in fresh leaves by a histochemical test and quantified morphometrically by point-counting analysis. The summer leaves (August) of $O$. vulgare contained the highest amounts of phenolics, as compared to $M$. spicata and $C$. vulgare. Phenolics were abundant in all leaf tissues (upper and lower epidermis, palisade and spongy parenchyma) of $O$. vulgare, but mainly in epidermal cells of $M$. spicata. In case of C. vulgare, however, phenolics were mostly present in the spongy parenchyma of the mesophyll. High amounts of phenolics in the summer leaves of these aromatic plants appeared to impart protection from harmful insects, microorganisms, and drought stress, rather than from UV-B radiation.
\end{abstract}

Keywords: aromatic plants, phenolics, leaf anatomy, ultrastructure, morphometry

\section{INTRODUCTION}

Phenolics are secondary metabolites that widely occur in plant tissues. They comprise a very large and diverse group of compounds characterized by a benzene ring and one or more hydroxyl substituents. These compounds arise biosynthetically from the shikimate, phenylpropanoid, and flavonoid pathways, producing monomeric and polymeric phenols and polyphenols (LATTANZIO et al. 2006). They have a wide spectrum of activities, principally associated with plant defence. They also play an important role in plant protection against frost stress (Liv et al. 2007), drought stress (Weidner et al. 2009), heavy metal toxicity (BARCELó \& PosChENRIEDER 2002), UVB radiation (CARLETTI et al. 2003), excessive light (TATTINI et al. 2004), microbial infection (HARBORNE \& Williams 2000), insect attack (LATTANZIO et al. 2006), etc. It is, therefore, essential for the plant to invest a significant amount of photosynthetic carbon towards the biosynthesis of phenolics. 
Phenolics accumulate principally in the leaf epidermis as a first line of plant defence. They may also accumulate temporarily in the mesophyll (photosynthetic parenchyma) or in idioblastic cells, and are mobilized via the symplast and the apoplast to the vascular tissues, through which they reach the sites of defence.

In the present report, the accumulation of phenolics in the summer leaves of 3 species of aromatic plants was investigated morphometrically (point-counting analysis) using light and transmission electron microscopy. Summer months comprise the most appropriate collection period of these plants since their development and their essential oil content reach a maximum then. The findings were expected to indicate the significance of the contained phenolics in plant defence and adaptation.

\section{MATERIAL AND METHODS}

\section{Plant material}

The species Origanum vulgare L., Mentha spicata L., and Clinopodium vulgare L. (Lamiaceae) were studied. Origanum vulgare is widely distributed in most of Europe and Asia. It occurs in all types of ecosystems, ranging from the extremely dry Mediterranean regions to mountainous forests, from the sea level up to over 2000 $\mathrm{m}$ of altitude in Greece. Mentha spicata is native only to the Balkan peninsula and northern and western Turkey, but the species was introduced and naturalized throughout most of Europe and North America. It is the most widespread native species of Greece, found up to $2000 \mathrm{~m}$ of altitude. Clinopodium vulgare is distributed almost all over the temperate regions of the northern hemisphere. In Greece, it is scattered throughout the mainland and on several of its islands. It occurs in macchia and open woodlands at a range of altitudes from near the sea level to about $2200 \mathrm{~m}$ of elevation.

Native populations of Origanum vulgare, Mentha spicata, and Clinopodium vulgare were studied at the foot of Mt. Pangaion (also known as Pangaion Hills) in North Greece (200 m a.s.1., 40 $55^{\prime} \mathrm{N}, 2^{\circ} 14^{\prime} \mathrm{E}$, macchia vegetation). Plant material was collected in 1999, at the beginning (June) and end (August) of summer, always early in the morning and on the same sites of the populations, so that the results are comparable. Young but fully developed leaves of annual stems were sampled from different plants, always from their southern side.

\section{Histochemistry}

For identification of phenolic compounds, a histochemical test was conducted on fresh leaves. Free-hand sections were treated with equal volumes of reagents in the following succession: $10 \%$ sodium nitrate, $20 \%$ urea, $10 \%$ acetic acid for $3 \mathrm{~min}$ each, and after 3-4 min, with 2 volumes of $2 \mathrm{~N}$ sodium hydroxide. Positive reaction produces a range of colour, from red to yellow (REEVE 1951).

\section{Microscopy}

Small pieces of leaves were initially fixed in situ for $3 \mathrm{~h}$ with $5 \%$ glutaraldehyde in $0.05 \mathrm{M}$ phosphate buffer at $\mathrm{pH}$ 7.2. After washing in the buffer, the specimens were post-fixed for $2 \mathrm{~h}$ with $2 \%$ osmium tetroxide, similarly buffered. The temperature in 
all solutions was kept at $0^{\circ} \mathrm{C}$ to avoid leaching of the phenols during fixation. Samples were then dehydrated in an alcohol series and embedded in SPURR's (1969) epoxy resin. Semithin sections for light microscopy were obtained in a Reichert $\mathrm{Om}_{2}$ microtome, next stained with toluidine blue $\mathrm{O}$ and photographed in a Zeiss III photomicroscope. Ultrathin sections for transmission electron microscopy were cut using a Reichert-Jung Ultracut E ultramicrotome, next stained with uranyl acetate and lead citrate, and examined in a JEM 2000 FXII transmission electron microscope.

\section{Morphometry}

For the morphometric assessment of the relative volume of the phenolic compounds, a transparent sheet bearing a square lattice of point arrays, $10 \mathrm{~mm}$ apart, was laid over light micrographs of leaf sections $(\times 800)$. The point-counting analysis was then applied (STEER 1981).

\section{RESULTS AND DISCUSSION}

Paradermal sections (cut at the levels of the upper epidermis, palisade parenchyma, spongy parenchyma, and lower epidermis) of summer leaves of the 3 species were examined. In all cases, the accumulation of phenolics in the leaves emerging in August was higher than in those emerging in June (Table 1).

Table 1. Relative volume percentages (by point-counting analysis) of phenolics in summer leaves of Origanum vulgare, Mentha spicata, and Clinopodium vulgare

\begin{tabular}{lcc}
\hline \multirow{2}{*}{ Species } & \multicolumn{2}{c}{ Relative volume (\%) of phenolics } \\
\cline { 2 - 3 } & June & August \\
\hline Origanum vulgare & $6-10$ & $>20$ \\
Mentha spicata & $1-5$ & $16-20$ \\
Clinopodium vulgare & ND & $16-20$ \\
\hline
\end{tabular}

$\mathrm{ND}=$ not detected

Origanum vulgare leaves were found to contain the largest amounts of phenolics. These compounds were present only in the epidermis and not in the mesophyll of leaves that emerged during early summer (June), whereas they were abundant in all tissues of leaves that emerged in late summer (August) (Fig. 1A-D). Such an abundance of phenolics was not observed in leaves of the other 2 species. August leaves of M. spicata and C. vulgare contained more phenolics than June leaves. Moreover, June leaves of $C$. vulgare appeared to contain no such substances in any of their tissues. The high abundance of phenolic compounds in August leaves is mainly due to the more stressful conditions (higher temperatures and lower water availability) prevailing in late summer than at the beginning of summer. 


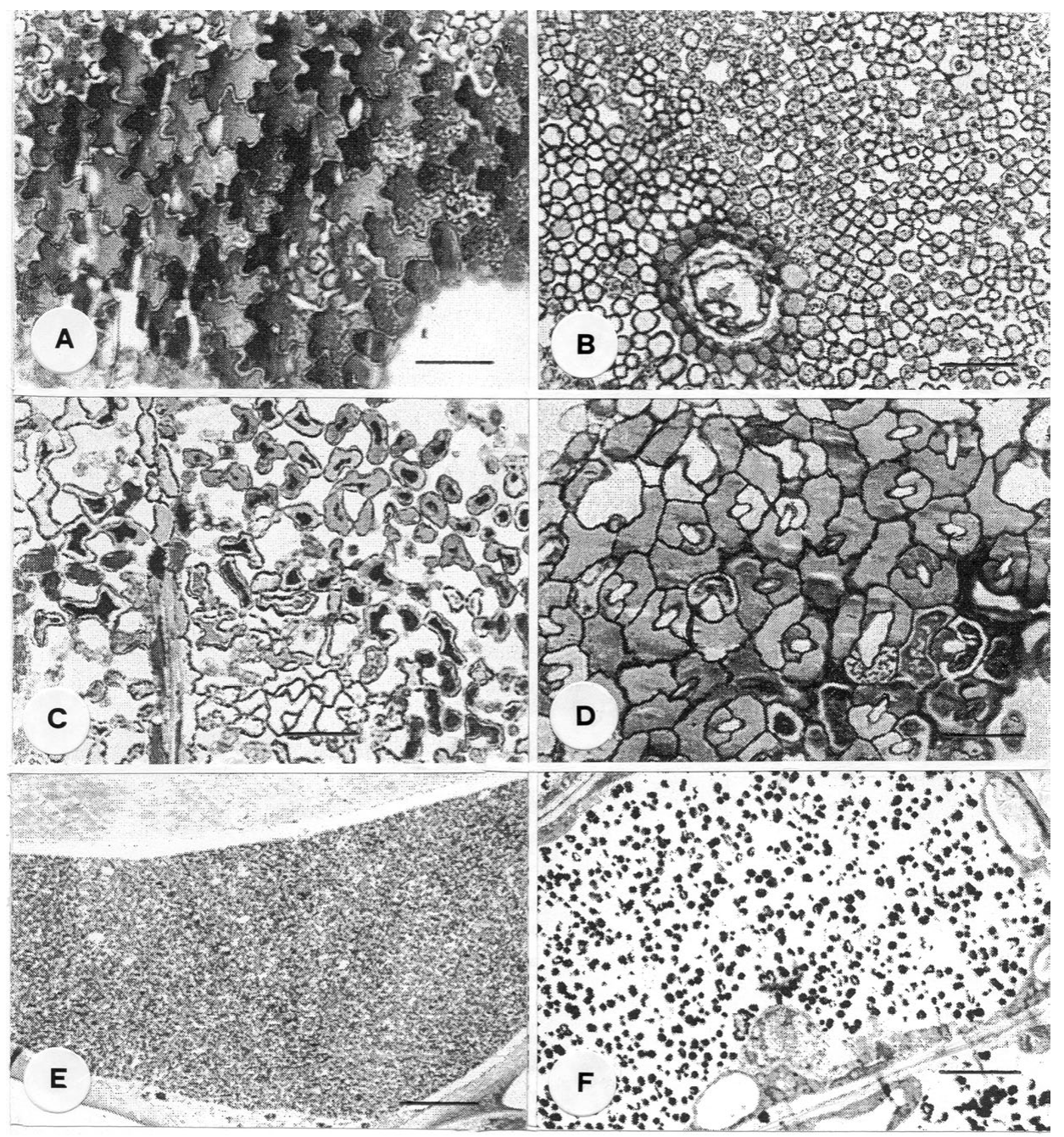

Fig. 1. Origanum vulgare. Serial leaf paradermal sections cut at the levels of the upper epidermis (A), palisade parenchyma (B), spongy parenchyma (C), and lower epidermis (D). Phenolics occur in all the tissues. Bar $=55 \mu \mathrm{m}$. Under the electron microscope, phenolics appear fine-granular in the epidermis (E) and dark globular in the mesophyll (F). Bar $=3 \mu \mathrm{m}$ 


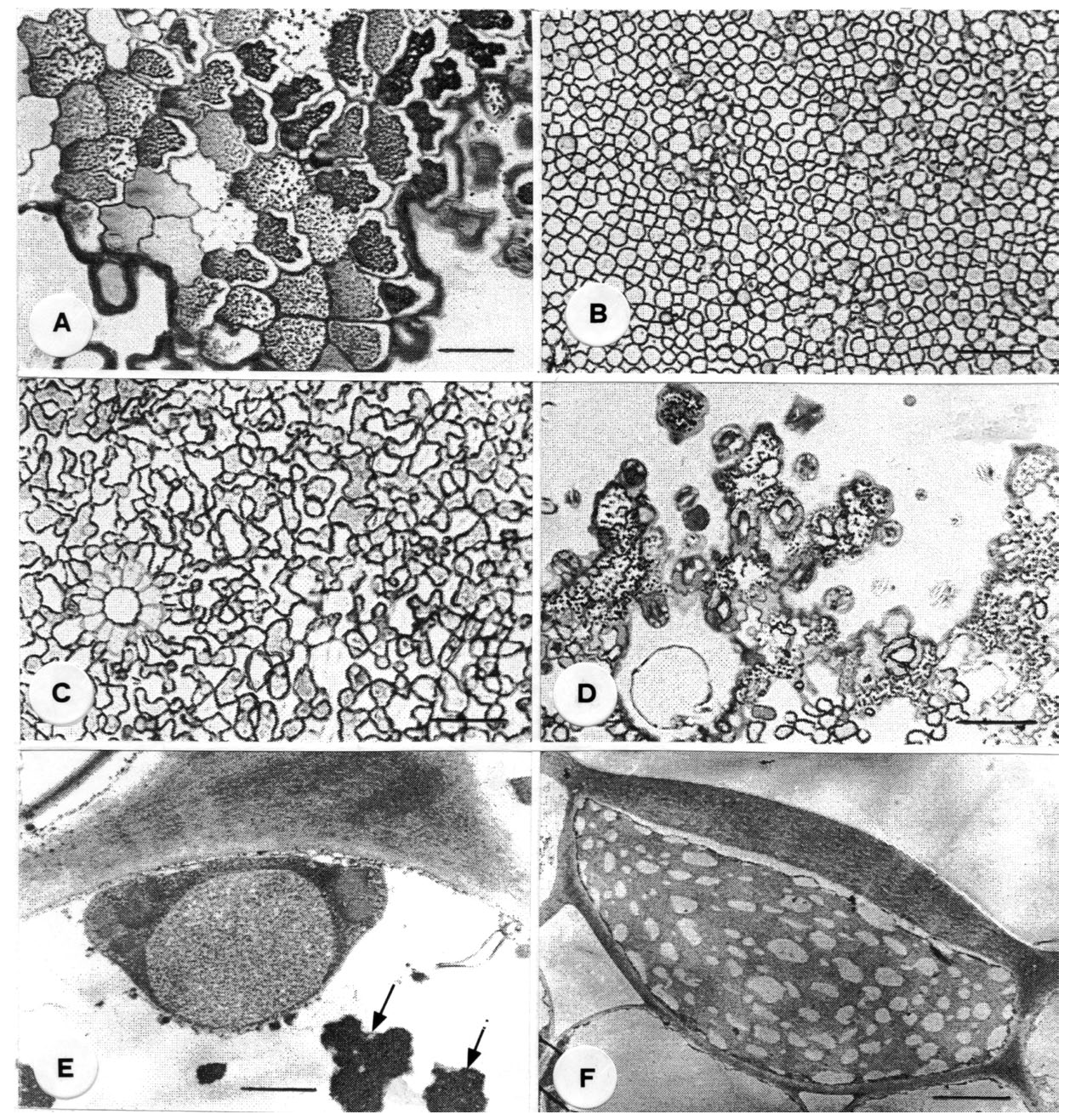

Fig. 2. Mentha spicata. Serial leaf paradermal sections cut at the levels of the upper epidermis (A), palisade parenchyma (B), spongy parenchyma (C), and lower epidermis (D). Phenolics mainly occur in the upper and lower epidermis. Bar $=55 \mu \mathrm{m}$. Under the electron microscope, phenolics appear either as scattered irregular electron-dense accumulations (E, arrows; bar $=0.7 \mu \mathrm{m})$, or as an electron-opaque substance containing transparent droplets $(\mathrm{F} ; \mathrm{bar}=4 \mu \mathrm{m})$ 


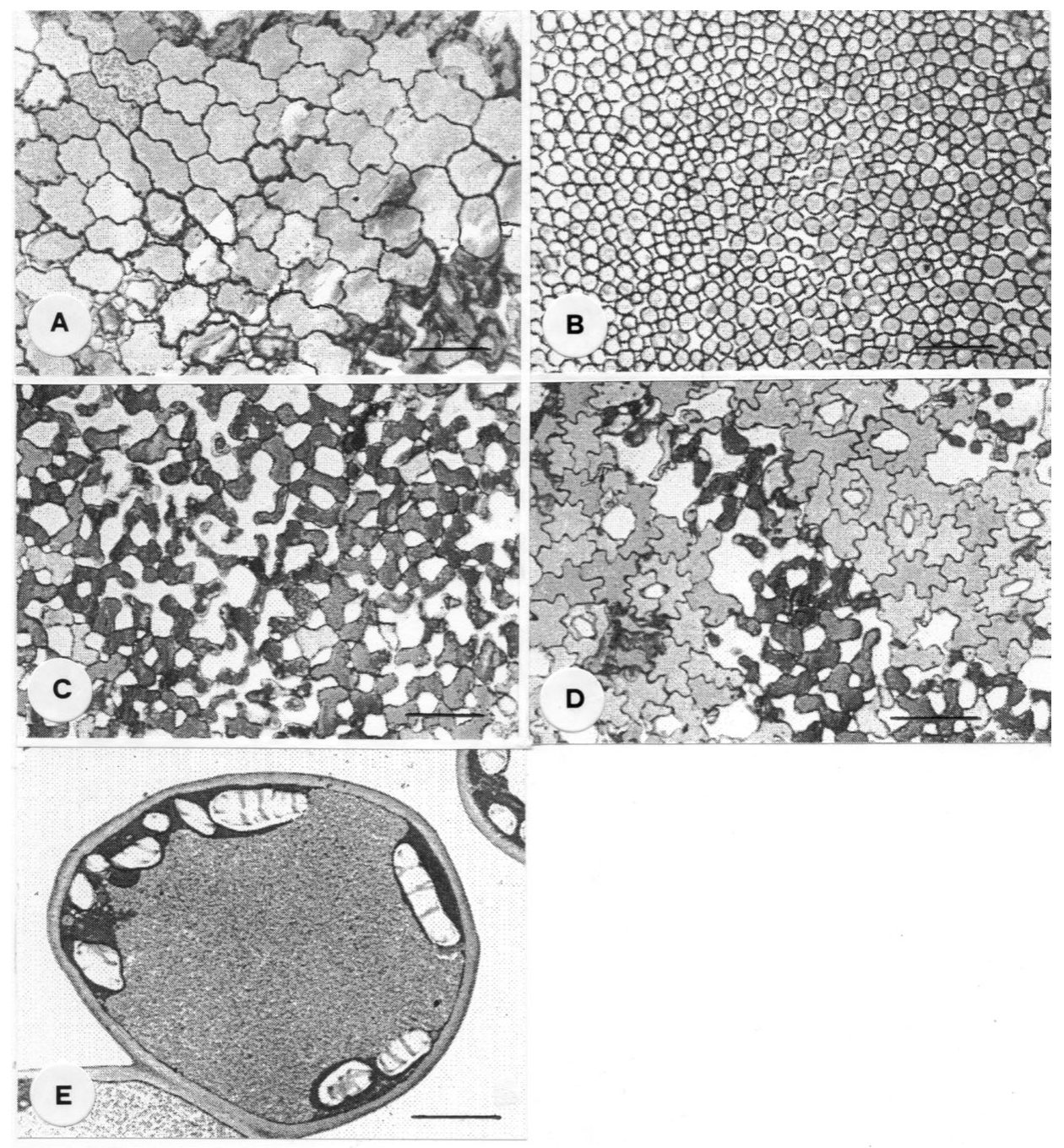

Fig. 3. Clinopodium vulgare. Serial leaf paradermal sections cut at the levels of the upper epidermis (A), palisade parenchyma (B), spongy parenchyma (C), and lower epidermis (D). Phenolics mainly occur in the spongy parenchyma. Bar $=55 \mu \mathrm{m}$. Under the electron microscope, phenolics appear in the vacuoles of spongy parenchyma cells as a fine-granular mass $(E ; b a r=4 \mu \mathrm{m})$ 
Electron microscopic study of leaf sections revealed fine granules of vacuolar phenolics in epidermal cells (Fig. 1E), but small dark globules in mesophyll cells (Fig. 1F). The relative volume percentages of the phenolics are given in Table 1 .

In Mentha spicata, a higher relative volume of phenolics was observed in the leaves that emerged in August, as compared to the leaves that emerged in June (Table 1). These compounds were mainly present in epidermal cells than in mesophyll cells (palisade and spongy parenchyma) (Fig. 2A-D).

Ultrastructural observations revealed differences in the form of the phenolics. In most epidermal cells, vacuolar phenolics appeared as electron-dense individual accumulations (Fig. 2E, arrows), while in some others as a homogenous substance of low electron density, containing transparent droplets (Fig. 2F). Phenolics having analogous forms have been also observed in the leaves of Sarcopoterium spinosum (Christodoulakis et al. 1990).

Phenolic compounds had fine granular appearance and were mostly localized in the spongy parenchyma cells of $C$. vulgare mesophyll (Fig. 3C). These appeared to fill the vacuoles (Fig. 3E). The relative volume percentage of the phenolics in $C$. vulgare leaves is given in Table 1.

The anatomical analysis revealed that the phenolics accumulated in the leaf epidermal and mesophyll cells of the 3 species particularly during summer (August). An earlier report that phenolics play a role in absorption of UV-B irradiance (KoNDO \& KAWASHIMA 2000) was not confirmed in our study. Since UV increases with altitude (5-8\% per vertical kilometre, MADRONICH 1993), plants of lowland habitats are expected to contain low levels of phenolics. Thus it seems more likely that the patterns of phenolic accumulation in the studied plants are ecophysiologically implicated in defence against harmful insects and microorganisms, which abound in summer in lowland habitats (SUZUKI 1998). The high air temperature and water deficiency, which prevail at low altitudes, may further result in the development of drought stress, while phenolics can protect them from this stress (KHAN et al. 2011).

\section{REFERENCES}

Barceló J., Poschenrieder C. 2002. Fast root growth responses, root exudates and internal detoxification as clues to the mechanisms of aluminium toxicity and resistance: a review. Environ. Exp. Bot. 48: 75-92.

Carletti P., Masi A., Wonisch A., Grill D., Tausz M., Ferretti M. 2003. Changes in antioxidant and pigment pool dimensions in UV-B irradiated maize seedlings. Environ. Exp. Bot. 50: $149-157$.

Christodoulakis N. S., Tsimbani H., Fasseas C. 1990. Leaf structural peculiarities in Sarcopoterium spinosum, a seasonally dimorphic subshrub. Ann. Bot. 65: 291-296.

Harborne J. B., Williams C. A. 2000. Advances in flavonoid research since 1992. Phytochemistry 55: 481-504.

Khan T. A., Mazid M., Mohammad F. 2011. Status of secondary plant products under abiotic stress: an overview. J. Stress Physiol Biochem. 7: 75-98. 
Kondo N., Kawashima M. 2000. Enhancement of the tolerance to oxidative stress in cucumber (Cucumis sativus L.) seedlings by UV-B irradiation: possible involvement of phenolic compounds and antioxidative enzymes. J. Plant Res. 113: 311-317.

Lattanzio V, Lattanzio V. M. T., Cardinali A. 2006. Role of phenolics in the resistance mechanisms of plants against fungal pathogens and insects. In: Phytochemistry: Advances in Research (ImPERATo F., Ed.), pp. 23-67, Research Signpost, India.

Liu M., Chen Y., Lu C., Zhang H., YIN W. 2007. Cold acclimation induced accumulation of phenolic compounds and freezing tolerance in Ammopiptanthus mongolicus. For. Stud. China 9: 203-207.

Madronich S. 1993. The atmosphere and UV-B radiation at ground level. In: Environmental UV photobiology (Young A.R., Ed.), pp. 1-39, Plenum Press, New York.

ReEve R. M. 1951. Histochemical tests for polyphenols in plant tissues. Biotech. Histochem. 26: 91-96.

SpURR A. R. 1969. A low viscosity epoxy resin embedding medium for electron microscopy. J. Ultrastruct. Res. 26: 31-43.

Steer M. W. 1981. Understanding cell structure. Cambridge Univ. Press, Cambridge.

SuzUKI S. 1998. Leaf phenology, seasonal changes in leaf quality and herbivory pattern of Sanguisorba tenuifolia at different altitudes. Oecologia 117: 169-176.

Tattini M., Galardi C., Pinelli P., Massai R., Remorini D., Agati G. 2004. Differential accumulation of flavonoids and hydroxycinnamates in leaves of Ligustrum vulgare under excess light and drought stress. New Phytol. 163: 547-561.

Weidner S., Karolak M., Karamać M., Kosińska A., Amarowicz R. 2009. Phenolic compounds and properties of antioxidants in grapevine roots (Vitis vinifera L.) under drought stress followed by recovery. Acta Soc. Bot. Pol. 78: 97-103. 